\title{
НЕЗАВИСИМЫЕ МЕДИА И ИНИЦИАТИВЫ ГОСУДАРСТВЕННОЙ СЕМЕЙНОЙ ПОЛИТИКИ НА ЭТАПЕ «ПРОНАТАЛИСТСКОГО ПОВОРОТА»
}

В статье анализируется изменение фреймирования семейных отношений в текстах независимых СМИ до и после «пронаталистского поворота» семейной политики в 2006 г. Автор опирается на модель Пирса Робинсона, согласно которой только в ситуации политической неопределенности СМИ предлагают различные позиции и критику. Проблематизируется способность массмедиа выстраивать не только стратегии подчинения политической власти, но и стратегии сопротивления, особенно в случаях, когда СМИ позиционируют себя как независимого агента политического влияния. В качестве инструмента сбора эмпирических данных используется культуромика - метод исследования культурных и социальных процессов с помощью статистического анализа употребления слов и словосочетаний в значительных текстовых массивах. На основе статистического анализа употребления слов в изучаемых массмедиа выделяется фрейм-структура «семья», типичная для определенного периода. На основе статистического анализа употребления словосочетаний анализируется содержание статей, описывающих семейные отношения в СМИ. Материалом исследования выступили архивы «Газета.Ru», «Коммерсантъ», «РБК», «Новой газеты» за 16 лет (2000-2015 г.). Согласно результатам исследования, изучаемые СМИ практически не используют стратегии сопротивления. Так, «Газета.Ru» включается в пронаталистский дискурс, используя практики рефрейминга, формулирует иную точку зрения на ряд аспектов государственной семейной политики. «РБК», практикуя стратегию развлечения, поддерживает государственный пронатализм. «Коммерсантъ» одновременно игнорирует «пронаталистский поворот» и использует рефрейминг традиционной семейной тематики. «Новая газета» игнорирует «пронаталистский поворот». Выдвигается предположение,

Надежда Константиновна Радина - д.п.н., профессор, департамент социальных наук, Национальный исследовательский университета Высшая школа экономики, Нижний Новгород, Россия. Электронная почта: nradina@hse.ru, rasv@yandex.ru 
что политические элиты в России не рассматривают семейную политику как пространство реализации политических интересов. Критика «пронаталистского поворота», разделяемая исследователями, не поддерживается российской политической элитой.

Ключевые слова: семейная политика, массмедиа, пронатализм DOI: $10.17323 / 727-0634-2018-16-2-295-310$

В 2006 г. в Послании Президента Федеральному Собранию сформулированы положения относительно изменений в области семейной политики (Путин 2006), которые исследователи назовут началом «пронаталисткого поворота» российской семейной политики (Чернова 2011). Пронаталистский поворот далее конкретизируется в Концепции демографической политики на период до 2025 г., других нормативных документах (Госдума 2014), что расколет исследователей семьи на тех, кто станет множить варианты доминирующего пронаталистского нарратива (Отделкина 2013), и тех, кто критически оценивая ресурсы пронаталистского поворота, будет предлагать иные пути развития семейной политики (Печерская 2012; Ярская-Смирнова 2010; Rivkin-Fish 2010).

Анонсированные в послании идеи о семейной политике не остались лишь декларацией и трансформировались в законодательные инициативы: например, «материнский капитал», сокращение социальных показаний к абортам (Печерская 2012). Проделана большая пропагандистская работа введены новые праздники, конкурсы и соревнования, ориентированные на семью и «традиционные семейные ценности», транслировалась социальная реклама, призывающая к рождению детей и улучшению демографической ситуации (Ярская-Смирнова 2010). Современная пронаталистская практика цитирует позднее советское прошлое с его патримониальной и этакратической гендерной системой (Здравомыслова, Темкина 2007), предполагающей, что кроме мужчины и женщины «третий» в семье не ребенок, а регулирующее семейные отношения государство. В статье анализируется реакция негосударственных медиа на пронаталистский поворот в государственной семейной политике и характеризуются возможные стратегии нарративного сопротивления пронаталитстским инициативам.

\section{Власть и влияние: роль массмедиа}

«То, что мы знаем о нашем обществе и даже мире, в котором живем, мы знаем благодаря массмедиа»,- тезис Никласа Лумана (2005: 8) в контексте анализа любой пропагандистской активности приобретает особое значение. Именно коммуникация организует смысловое пространство общества, формирует то, что впоследствии принимается как «знание» или «истина». При этом коммуникативный код является такой структурой коммуникации, 
«которая для каждого произвольного элемента в пределах своей области релевантности может найти и упорядочить другой дополнительный элемент» (Луман 2001:54), поэтому код власти тесно связан с кодом массмедиа. Коммуникативный код власти объясняет главенство доминирующих в обществе нарративов в поддержку определенного видения, прочтения, позиции, нуждающихся в воспроизводстве. На уровне индивида принятие и воспроизводство доминирующих нарративов объясняется механизмами социализации (интернализацией, подражанием, конформизмом), благодаря которым происходит индивидуальная адаптация. Поэтому «политический субъект»-это прежде всего подчиненный субъект (Батлер 2002: 23).

На уровне массмедиа, включенных в дискурсивное поле политического действия и политической власти, при этом обладающих властью и претендующих на дискурсивное создание мира, в котором существует само общество, проблема подчинения (политической) власти представляется более драматичной. Перед СМИ, конституирующими массмедийное пространство, встает выбор: встраиваться в логику трансляции доминирующих нарративов (подчиниться им) или претендовать на производство иной точки зрения, иной структуры интерпретаций и иной картины мира. Тем не менее, согласно выводам исследователей, СМИ преимущественно конформистски ориентированы в отношении официальной политики государства (Dispensa, Brulle 1981; Olausson 2009).

Пирс Робинсон, объясняя феномен медиатизации политики ${ }^{1}$, описывает модель «взаимодействия политики и СМИ» (policy-media interaction model), согласно которой только в ситуации политической неопределенности СМИ предлагают различные позиции и критику (Robinson 2001). Если политические элиты способны прийти к соглашению, то вероятность, что в СМИ появится критика по этому вопросу, крайне мала.

Анализ публикаций правительственных СМИ до и после 2006 г. показал, что данные медиа успешно вписались в пронаталистский дискурс, доминирующий после послания президента, транслируя пронаталистские ценности и изменяя прежнюю приверженность иным семейным моделям (Радина 2017). В продолжение анализа стратегий массмедиа в области конструирования смыслов и ценностей современной семейной политики важно изучить материалы СМИ, которые считаются независимыми, но вынуждены писать о семье, находясь в окружении доминирующего пронаталистского дискурса.

\section{Описание программы исследования}

Представленное исследование, посвященное изучению стратегий нарративного сопротивления независимых массмедиа инициативам российской семейной политики на этапе пронаталистского поворота, композиционно

\footnotetext{
${ }^{1}$ Процесс проникновения политического поля в медийное, в результате которого наблюдается перемещение политических смыслов в медийную область.
} 
построено таким образом, что сравнительному анализу подлежат материалы, опубликованные до и после Послания Президента Федеральному Собранию 2006 г. Часть из них, посвященная семье, представляет эклектичный период семейной политики (до 2006 г. включительно), вторая часть - пронаталистский (после 2006 г.). В исследовании применялись методы компьютерной лингвистики, позволяющие анализировать статистику текста (ipm, PMI).

В качестве центрального метода выбрана «культуромика» - новый метод исследования культурных и социальных процессов с помощью статистического анализа употребления слов и словосочетаний в значительных текстовых массивах (Бонч-Осмоловская 2015). На основе статистики текста реконструировался структурный фрейм семьи (семейных отношений), воспроизводящийся в текстах массмедиа. Эталонный фрейм-структура «семья» сформирован на основе словарных статей, согласно которым семья определяется через ее структуру, а именно как группа живущих вместе близких родственников (Ожегов, Шведова 2006). Таким образом, структурный фрейм, отражающий структуру понятия, реконструирован посредством ролевой структуры семьи.

Фрейм-структура «семья» (до 2006 г. и после) для изучаемых СМИ строилась с использованием программного обеспечения - AntConc, Content Analyzer на основе ключевых слов: супруги, муж, жена, дети, ребенок, родственники, родители, мать (мама), отец (папа), бабушка, дедушка. Подобный набор элементов структуры семьи отражает историческую динамику взглядов на описание социальной структуры семьи - от традиционной расширенной семьи (включающей несколько поколений) к современной нуклеарной (состоящей из одного или обоих родителей и детей).

Сформулировано предположение, согласно которому в каждой статье, посвященной семье, ее концепция реализуется посредством истории с действующими лицами - членами семьи. Структура семьи в тексте одной статьи является конкретизацией общего фрейма, описывающего структуру понятия. Анализ массива текстов статей на основе частотности упоминаний тех или иных структурных единиц («слотов») фрейма может показать, какая концепция доминирует в представленной коллекции текстов. Центральными слотами в реконструированных фреймах считались слоты с максимальным весом (частотностью), поскольку именно они представляют наиболее значимых, с точки зрения журналистов, членов семьи (о них чаще говорят в публикациях). Важным допущением при создании исследовательской программы стало представление о социальном знании как подвижной и изменяющейся области, следовательно, с изменением представлений о семье (с изменением понятия «семья»), изменяется и структура (иерархия) элементов в описании данного понятия.

При анализе в процессе построения фрейм-структуры «семья» для каждого СМИ используются коэффициент ipm (instances per million words), показывающий, насколько частотным является то или иное словоупотреб- 
ление на миллион слов (Michel et al. 2010) и коэффициент PMI (Pointwise Mutual Information) $)^{1}$ для определения статистики коллокаций с ключевыми словами (коллокация - устойчивое словосочетание; в данном исследовании используется в форме триграмм²).

В качестве материалов использованы архивы популярных негосударственных СМИ, но только те материалы, которые так или иначе ориентированы на семейную проблематику (тексты идентифицировались по ключевым словам: семья, мать/мама, отец/папа, ребенок, дети, бабушка, дедушка, родственники):

- «Газета.Ru»- общественно-политическое интернет-издание, ведущее круглосуточное освещение российских и мировых новостей (в 20002006 гг.- 1652 статей, 1162094 слов; в 2007-2015 гг.- 1375 статей, 1062074 слов);

- «Коммерсантъ»- российская ежедневная общественно-политическая газета с усиленным деловым блоком (в 2000-2006 гг.- 1852 статей, 1581809 слов; в 2007-20015 гг.-2449 статей, 2028613 слов);

- «РБК»- ежедневная аналитическая газета, входящая в медиагруппу «РосБизнесКонсалтинг» (в 2000-2006 гг.-1 136 статей, 331677 слов; в 2007-20015 гг.-2212 статей, 1059378 слов);

- «Новая газета»- российская еженедельная общественно-политическая газета, которая занимается журналистскими расследованиями (в 2000-2006 гг.- 1148 статей, 1889122 слов; в 2007-2015 гг. - 2487 статей, 4863519 слов).

Основных стратегий интерпретации пронаталистской семейной политики со стороны негосударственных СМИ может быть три: принятие пронаталистской семейной политики посредством воспроизведения в публикациях доминирующего пронаталистского нарратива; игнорирование «пронаталистского поворота», включая игнорирование семейной проблематики в целом; сопротивление пронаталистской политике путем представления своей версии семейных отношений. Именно стратегия сопротивления пронаталистской политике государства, отраженная в нарративах неправительственных медиа, представляет интерес для нашего исследования.

\section{Семейные отношения на страницах «Газета.Ru»}

B «Газете.Ru» за исследуемый период уменьшилось число публикаций, так или иначе касающихся темы «семья» (в среднем 236 в год до 2006 г. и 153 после, то есть в полтора раза), что тем не менее, не отразилось на «плотности» описания семейных проблем: упоминание ключевых слов

\footnotetext{
${ }^{1}$ Согласно статистике текста, значение имеют показатели МРІ только более 3.

2 Триграмма - словосочетание из трех слов.
} 
«дети» и «ребенок» увеличилось соответственно более чем в полтора и два раза (табл. 1).

Таблийа 1

Фрейм-структура «семья» в публикациях «Газета.Ru» (ipm)

\begin{tabular}{cllllll}
\hline Период & \multicolumn{5}{c}{ Эмпирически выявленные ведуцие слоты фрейма } \\
\hline $2000-2006$ Эклектика & детей & ребенка & мать & отец & жена & родители \\
& $(1324)$, & $(592)$, & $(376)$, & $(345)$, & $(326)$, & $(314)$, \\
& дети & ребенок & матери & отца & жены & родителей \\
& $(584)$, & $(239)$ & $(207)$ & $(234)$ & $(208)$ & $(289)$ \\
\hline $2007-2015$ Пронатализм & детей & ребенка & мать & родители & отец & жена \\
& $(2251)$, & $(1449)$, & $(758)$, & $(592)$, & $(590)$, & $(531)$, \\
& дети & ребенок & матери & родите- & отца & жены \\
& $(762)$, & $(510)$ & $(385)$ & лей (628) & $(363)$ & $(286)$ \\
\hline
\end{tabular}

Если до 2006 г. в публикациях, отобранных на основе использования ключевого слова «семья», частотность упоминания в текстах членов семьи ниже, чем в целом в общем корпусе НКРЯ 1 (в НКРЯ «ребенок» (ipm 658), «отец» (ipm 484), «жена» (ipm 377), «муж» (ipm 263), «мать» (ipm 330) и «мама» (ipm 323)) (Ляшевская, Шаров 2009), то, начиная с 2007 г., «плотность» описания семейных отношений в публикациях «Газета.Ru», посвященных семье, значительно увеличилась. Ведущие триграммы до 2006 г. представляли доминирование скорее «мужских историй»: «мы с женой» (MPI 12), «с женой и» (MPI 11), «со своей женой» (MPI 11), «и его жена» (MPI 9), «жены и детей» (MPI 8). «Женские версии» чаще предлагали позицию от первого лица и по частотности уступали «мужским»: «мы с мужем» (MPI 14) и «с мужем и» (MPI 8) (табл. 2).

Таблица 2

Десять наиболее частотных триграмм: «Газета.Ru» (MPI)

\begin{tabular}{|c|c|}
\hline $2000-2006$ & $2007-2015$ \\
\hline $\begin{array}{l}\text { мы с мужем (14), детей в возрасте (14), с деть- } \\
\text { ми и (12), мы с женой (12), у которых дети } \\
(12), \text { с женой и (11), со своей женой (11), и их } \\
\text { родственников (10), ребенка из России (10), } \\
\text { муж и жена (10), и его жена }\end{array}$ & $\begin{array}{l}\text { по правам ребенка (73), без попечения ро- } \\
\text { дителей (26), с женой и (25), и его жена (25), } \\
\text { правам ребенка и (23), и ее муж (22), с деть- } \\
\text { ми и (21), вместе с женой (20), и его супруга } \\
(19), \text { бабушки и дедушки (18) }\end{array}$ \\
\hline
\end{tabular}

После 2006 г., на пронаталистском этапе, показатели MPI в триграммах текстов о семье выросли в пять раз, что свидетельствует о высокой кли-

\footnotetext{
${ }^{1}$ НКРЯ - Национальный корпус русского языка.
} 
шированности текстов. Так, ключевая позиция в текстах о семье у триграммы «по правам ребенка» (MPI 73), также высокая встречаемость у триграмм «без попечения родителей» (MPI 26) и «правам ребенка и» (MPI 23). Триграммы с высокой частотностью раскрывают темы сиротства и усыновления, доминирующие в публикациях о семье пронаталистского этапа, в том числе зарубежном усыновлении: «ребенка из России» (MPI $15)$, «детей из России» (MPI 9), «усыновление российских детей» (MPI 15), «детей оставшихся без» (MPI 14).

Отвечая на вопрос, насколько «Газета.Ru» воспроизводит «пронаталисткий дискурс», необходимо отметить определенную интригу в позиции газеты. С одной стороны, исследуемое СМИ создает детоцентристский мир семьи, где наиболее значимы дети и отчасти мать. В то же время в процессе работы на поле доминирующих нарративов СМИ представляет критический взгляд, особенно это касается изменения порядка зарубежного усыновления. Следовательно, позиция «Газета.Ru» в отношении государственной пронаталистской семейной политики строится на основе принятия государственной повестки, однако с сохранением критического потенциала и даже с практиками рефрейминга, возможностью формулировать иную точку зрения на некоторые аспекты семейной политики (как правило, несогласие сводится к критике изменения порядка зарубежного усыновления).

\section{Семейные отношения на страницах газеты «Коммерсантъ»}

В газете «Коммерсантъ», судя по числу публикаций до и после 2006 г. (в среднем в год 265 статьей до 2006 г. и 272 - после), «пронаталистский поворот», на первый взгляд, оказался незамеченным (табл. 3). Все показатели частотности встречаемости ключевых слов от периода эклектики до периода пронатализма снизились, кроме ключевого слова «ребенок»: ipm 510 после 2006 г., встречаемость повысилась в полтора раза. Однако показатели не достигли «нормы», типичной для обобщенной коллекции текстов в НКРЯ, где «ребенок» имеет ipm 658. Связывать эту динамику с пронаталистским этапом весьма спорно, поскольку у «Коммерсанта» есть редакционные проекты, где дети играют ведущую роль - это благотворительные проекты, ориентированные на сбор средств и помощь нуждающимся.

Образ семьи, создаваемый на страницах газеты «Коммерсантъ»,-это «традиционный» брачный союз, где дети - важный элемент, но производный от супружеских отношений. Пронаталистская тематика после 2006 г. вторгается в содержание газеты «Коммерсантъ» в форме обращения к правам ребенка: триграмма «по правам ребенка» (MPI 56), «правам ребенка Павел [Астахов]» (MPI 8). Эта тема также связана с проблемой зарубежного усыновления: триграмма «усыновление российских детей» с MPI 8 (табл. 4). 
Таблиия 3

Фрейм-структура «семья» в публикациях «Коммерсантъ» (ipm)

\begin{tabular}{cllllll}
\hline \multicolumn{1}{c}{ Период } & \multicolumn{5}{c}{ Эмпирически выявленные ведущие слоты фрейма } \\
\hline $2000-2006$ Эклектика & детей & мать & жена & отец & ребенка мужа \\
& $(1019)$, & $(556)$, & $(507)$, & $(455)$, & $(332)$ & $(321)$, \\
& дети & матери & жены & отца & & муж \\
& $(636)$, & $(225)$ & $(245)$ & $(336)$ & & $(310)$ \\
\hline $2007-2015$ Пронатализм & детей & ребенка & мать & отец & жена & родите- \\
& $(1015)$, & $(512)$, & $(403)$, & $(387)$, & $(343)$ & лей (307), \\
& дети & ребенок & матери & отца & & родители \\
& $(472)$, & $(510)$ & $(385)$ & $(324)$ & & $(297)$ \\
\hline
\end{tabular}

Таблий 4

Десять наиболее частотных триграмм: «Коммерсантъ» (MPI)

\begin{tabular}{|c|c|}
\hline $2000-2006$ & $2007-2015$ \\
\hline $\begin{array}{l}\text { для детей (10), тележурнал для детей (32), } \\
\text { программа для детей (31), я спортивная семья } \\
(25) \text {, мама я спортивная (25), папа мама я (24), } \\
\text { и его жена (24), и его супруга (22), с женой } \\
\text { и (18), фильм для детей (18) }\end{array}$ & $\begin{array}{l}\text { по правам ребенка (56), и его жена (19), жен- } \\
\text { щин и детей (15), по вопросам семьи (13), } \\
\text { с женой и (12), его жена и (12), и ее муж (12), } \\
\text { без попечения родителей (12), семьи женщин } \\
\text { и (12), муж и жена (11) }\end{array}$ \\
\hline
\end{tabular}

Правовые вопросы, поставленные газетой «Коммерсантъ» и связанные с семьей, выносят на обсуждение не только права ребенка, но и в целом решение юридических проблем в контексте родственных отношений. Таким образом, в случае газеты «Коммерсантъ», ориентированной до 2006 г. на семью как супружество, пронаталистский поворот незначительно изменил редакционную политику.

\section{Семейные отношения на страницах «РБК»}

Число статей, связанных с семейной тематикой, в архивах РБК на этапе пронаталистсткого поворота увеличилось в полтора раза с 162 в среднем в год до 246 статей после 2006 г. (табл. 5). До 2006 г. при доминирующем внимании к детям в РБК супружеские отношения вытесняли детско-родительские - только ролевая позиция «мать» выбивается в лидеры (ipm 479). На пронаталистском этапе супружеские отношения в представлении семьи связаны с детско-родительскими: увеличилось число упоминаний ключевых слов «мать» (ipm 769) и «отец» (ipm 570).

Еще до пронаталистского периода в РБК обсуждали разные «семейные» темы и проблемы: это и вопросы усыновления детей, оставшихся без попечения родителей в России и за рубежом, и уход за родственниками, в том числе престарелыми и инвалидами, и различного рода трудности, 
связанные с воспитанием детей (табл. 6). Пронаталистский этап центрировал дискуссии о детях вокруг прав ребенка, однако в целом журналисты продолжали работу над темами сиротства и усыновления, детско-родительских отношений, публиковались также расследования о похищении детей и обличении насилия в отношении детей.

Таблица 5

Фрейм-структура «семья» в публикациях «РБК» (ірm)

\begin{tabular}{cllllll}
\hline Период & \multicolumn{5}{c}{ Эмпирически выявленные ведуцие слоты фрейма } \\
\hline $2000-2006$ Эклектика & детей & ребенка & жена & родителей & мужа & мать \\
& $(3196)$, & $(1987)$, & $(783)$, & $(654)$, & $(504)$, & $(479)$, \\
& дети & ребенок & жены & родители & муж & матери \\
& $(898)$ & $(245)$ & $(606)$ & $(458)$ & $(310)$ \\
& $(823)$, & & & & & \\
\hline $2007-2015$ Пронатализм & детей & ребенка & мать & родители & отец & супруга \\
& $(3147)$, & $(2694)$, & $(769)$, & $(694)$ & $(570)$, & $(476)$, \\
& дети & ребенок & матери & & отца & супруги \\
& $(652)$, & $(869)$ & $(454)$ & & $(305)$ & $(373)$ \\
\hline
\end{tabular}

Десять наиболее частотных триграмм: «РБК» (MPI)

\begin{tabular}{|c|c|}
\hline $2000-2006$ & $2007-2015$ \\
\hline $\begin{array}{l}\text { без попечения родителей (69), и его жена (54), } \\
\text { и двое детей (51), детей оставшихся без (48), } \\
\text { ребенка в возрасте (48), и ее муж (42), сирот } \\
\text { и детей (42), и детей оставшихся (42), детей в воз- } \\
\text { расте (39), за близкими родственниками (39) }\end{array}$ & $\begin{array}{l}\text { по правам ребенка (254), правам ребенка Па- } \\
\text { вел (Астахов) (75), правам ребенка в (65), без } \\
\text { попечения родителей (55), ребенка при пре- } \\
\text { зиденте (53), правам ребенка при (52), детей } \\
\text { оставшихся без (43), детей в возрасте (43), } \\
\text { в приемную семью (31), сирот и детей (30) }\end{array}$ \\
\hline
\end{tabular}

Журналисты РБК создавали драматичный и развлекательный нарратив о семье, не имеющий прямого отношения к дискуссиям о семейной политике или о гендерной системе общества, например:

В нашу эру высоких технологий трудно переоценить важность такого средства связи как мобильный телефон, в том числе и в сфере семейных отношений. $<\ldots>$ данное средство коммуникации все чаще используется парами для выяснения отношений (Ananova 2002).

Доминирующий «мужской взгляд» на семью, ворох исследований типа «исследований британских ученых» о семейных отношениях, поток фактов о сиротстве и усыновлении и едва заметная ирония в подаче новостей/ фактов в русле семейной политики характеризуют данный дискурс о семье, например: «Браки, заключенные до наступления 18 лет, 
для Чечни являются нормой. Об этом заявил уполномоченный по правам ребенка Павел Астахов в интервью» (РБК 2015).

РБК за исследуемый период становления семейной политики в России сформировало такую стратегию представления проблем семьи, которую по внешним критериям можно расценить как близкую государственной пронаталистской политике. Однако РБК не только поддерживает пронаталистский дискурс, но и развлекает (см., Carlson 1995) читателей забавными историями о семье, отвлекая от политического прочтения семейных отношений.

\section{Семейные отношения на страницах «Новой газеты»}

«Новая газета», согласно мнению журналистского корпуса, не просто независимое СМИ, а именно оппозиционное массмедиа (Livejournal.com 2012), поэтому анализ изменений в описании семейных отношений под давлением новой российской семейной политики представляется особенно значимым. После 2006 г. число публикаций с ключевыми словами о семье в «Новой газете» увеличилось в полтора раза со 164 в среднем и в среднем до 276 статьи в год после 2006 г. Согласно этим статьям, и до, и после начала «пронаталистского поворота», «Новая газета» в своих текстах воспроизводила своеобразную структуру семейных отношений (табл. 7).

Таблища 7

Фрейм-структура «семья» в публикациях «Новой газеты» (ipm)

\begin{tabular}{|c|c|c|c|c|c|c|}
\hline Период & & ипиричес & и выявл & ные ведуци & слоты фре & $\check{u ̆ m a}$ \\
\hline 2000-2006 Эклектика & $\begin{array}{l}\text { детей } \\
(1188), \\
\text { дети } \\
(770),\end{array}$ & $\begin{array}{l}\text { отец } \\
(476), \\
\text { отца } \\
(247), \\
\text { папа } \\
(186)\end{array}$ & $\begin{array}{l}\text { мать } \\
(400) \text {, } \\
\text { мама } \\
(383) \text {, } \\
\text { матери } \\
(209)\end{array}$ & $\begin{array}{l}\text { ребенка } \\
(389), \\
\text { ребенок } \\
(303)\end{array}$ & $\begin{array}{l}\text { жена } \\
\text { (323) }\end{array}$ & $\begin{array}{l}\text { родители } \\
(230)\end{array}$ \\
\hline 2007-2015 Пронатализм & $\begin{array}{l}\text { детей } \\
(1228), \\
\text { дети } \\
(621),\end{array}$ & $\begin{array}{l}\text { ребенка } \\
(584), \\
\text { ребенок } \\
(308)\end{array}$ & $\begin{array}{l}\text { отец } \\
(474), \\
\text { отца } \\
(238), \\
\text { папа } \\
(162)\end{array}$ & $\begin{array}{l}\text { мама (456), } \\
\text { мать (387), } \\
\text { матери } \\
\text { (194) }\end{array}$ & $\begin{array}{l}\text { родителей } \\
(335), \\
\text { родители } \\
(273)\end{array}$ & $\begin{array}{l}\text { муж } \\
(242), \\
\text { мужа } \\
(188)\end{array}$ \\
\hline
\end{tabular}

Своеобразие данной структуры в том, что привычная детоцентричность семьи здесь дополняется ролью «отца». На первый взгляд, данный факт может свидетельствовать в пользу «традиционной» семейной модели патриархатного типа, воспроизводимой на страницах издания. Однако в традиционном патриархатном нарративе ребенок неразрывно связан с матерью (в смысле заботы о ребенке). Более того, вытеснение матери 
фигурой отца в рассказах о семье, согласно адлерианской психоаналитической версии, есть признак заброшенности ребенка вне материнской любви (Сидоренко 2002). Доминирование отца при снижении значения роли матери в жизни ребенка или подростка - типичный авторский прием советских писателей (например, в произведениях А. Гайдара).

Другая особенность фрейм-структуры «семья» в «Новой газете»использование таких форм презентации ролей, которые редко встречаются в публицистическом повествовании, как «папа» (ipm 186) и «мама» (ipm 383).

Если же говорить о динамике фрейм-структуры «семья», то на пронаталистском этапе в публикациях «Новой газеты» усиливается женское видение семейных проблем - появление роли «муж» (ipm 242) после 2006 г., до 2006 г. более значима «жена» (ipm 323),- что характеризует мужскую речь и «мужской взгляд».

Содержательно публикации о семье в «Новой газете» выглядят следующим образом (табл. 8). Триграммы раскрывают взаимодействие как ключевую тему в материалах о семье. И до, и после 2006 г. триграммы характеризуют совместные действия, уточняя кто с кем в семье объединяется. Например, до 2006 г. «с женой и» (MPI 13), «с мамой и» (MPI 9), «вместе с детьми» (MPI 8). Дискурс прав ребенка присутствует в текстах как на этапе до «пронаталисткого поворота», так и после: «о правах ребенка» в 2006 г. (MPI 11) и «о правах ребенка» после 2006 г. (MPI 19).

Таблица 8

Десять наиболее частотных триграмм: «Новая газета» (MPI)

с женой и (13), о правах ребенка (11), мы с женой (10), женщин и детей (10), с мамой и (9), мама и папа (9), вместе с детьми (8), муж и жена (8), в доме ребенка (7), своих детей в (7) о правах ребенка (19), с женой и (11), мы с мужем (11), и его жена (10), для детей с (10), уходу за ребенком (10), мы с мамой (9), с детьми в (9), без попечения родителей (9), с детьми и (7)

Включение лингвистических форм семейных ролей таких как «мама», «папа», «бабушка», «дедушка» в контекст описания взаимодействия и семейной поддержки наполняет искренностью семейный дискурс оппозиционной газеты. Мир семьи на страницах «Новой газеты»- приватный мир личности, закрытый от политики и популизма. Это не поле для столкновения традиционалистских или современных дискурсов о семье, но закрытое пространство тех, кто, выбрав путь борьбы и сопротивления, всерьез не рассматривает «мирную жизнь в семье» как пространство реализации государственной семейной политики. 


\section{Заключение}

Анализ архивов независимых российских СМИ (а именно материалов, затрагивающих семейные темы) за 16 лет, с точки зрения возможных изменений, связанных с провозглашением «пронаталистского поворота» в семейной политике, показывает, что в реальности стратегии сопротивления доминирующим пронаталистским нарративам у независимых СМИ выглядят сложнее, чем представлялось первоначально. Согласно проведенному анализу, «Газета.Ru» и «РБК» принимают пронаталистский крен государственной семейной политики (с сохранением незначительного потенциала критики), а «Новая газета» и «Коммерсантъ» дистанцируются от активного обсуждения данных проблем.

Позиции негосударственных медиа свидетельствуют, по Робинсону, что политические элиты не сформировали единый взгляд на семейную политику, однако их точка зрения преимущественно не противоречит государственным установкам. Возможно, семейная политика в принципе не рассматривается политическими элитами как пространство для формулирования своей программы, что и обеспечивает стратегии несопротивления. Критика «пронаталистского поворота», звучащая из академического поля и разделяемая исследователями, не поддерживается массмедиа.

\section{Выражение благодарности}

Исследование выполнено при финансовой поддержке РГНФ в рамках научного проекта № 160300399.

\section{Список источников}

Ananova (2002) Телефонная связь - важная часть семейных отношений. РБК. Доступно по ссылке: https://www.rbc.ru/society/30/04/2002/5703b6c19a7947783a5a60eb (дата обращения: 17 мая 2018).

Livejournal.com (2012) Кому принадлежат оппозиционные СМИ или демократия для чайников. Доступно по ссылке: http://mobilization-ru.livejournal.com/754.htm (дата обращения: 15 декабря 2016).

Батлер Дж. (2002) Психика власти: теории субъекциии. СПб.: Алетейя.

Бонч-Осмоловская А.А. (2015) Культуромика в национальном корпусе русского языка, к постановке задачи: три века русских дорог. Труды института русского языка им. В. В. Виноградова, (6): 605-641.

Госдума (2014) Государственная семейная политика в Российской Федерации. Сборник материалов. М.: Издание государственной Думы.

Здравомыслова Е., Темкина А. (ред.) (2007) Российский гендерный порядок: сочиологический подход. СПб.: Издательство Европейского университета в СанктПетербурге. 
Луман Н. (2001) Власть. М.: Праксис.

Луман Н. (2005) Реальность массмедиа. М.: Праксис.

Ляшевская О.Н., Шаров С.А. (2009) Частотный словарь современного русского языка (на материалах Национального корпуса русского языка). М.: Азбуковник.

Ожегов С. И., Шведова Н. Ю. (2006) Толковый словарь русского языка. М.: ИТИ Технологии.

Отделкина Т.Н. (2013) Государственная семейная политика как фактор успешности развития семьи. Вестник Нижегородского университета им. Н. И. Лобачевского. Серия: Социальные науки, 2 (30): 44-47.

Печерская Н. (2012) Мифология родительства: анализ дискурсивного производства идеальной семьи. Журнал исследований сочиальной политики, 10 (3): 323-342.

Путин В.В. (2006) Послание Президента Федеральному Собранию Российской Федерации 2006 г. Доступно по ссылке: http://www.doxa.ru/analit/putin2006root.html (дата обращения: 15 декабря 2016).

Радина Н.К. (2017) Управление массмедийным дискурсом как функция коммуникативного кода власти. Политическая наука, (2): 138-156.

РБК (2015) Астахов назвал нормальными и законными ранние браки в Чечне. Доступно по ссылке: https://www.rbc.ru/rbcfreenews/5554c7fa9a7947ece0172af9 (дата обращения: 17 мая 2018).

Сидоренко Е. В. (2002) Терапия и тренинг в концепции Альфреда Адлера. СПб.: Речь.

Чернова Ж. В. (2011) Семейная политика в современной России: «пятый нацпроект». Человек. Сообщество. Управление, (2): 100-113.

Ярская-Смирнова Е. (2010) «Да-да, я вас помню, вы же у нас неблагополучная семья!» Дискурсивное оформление современной российской политики. Женщина в российском обществе, (2): 14-25.

Carlson J. (1995) Television Entertainment and Political Socialization. P. Vermeer (ed.) 'Media' Res: Readings in Mass Media and American Politics. New York: McGraw-Hill:47-55.

Dispensa J. M., Brulle R. J. (1981) Media's social construction of environmental issues: focus on global warming - A comparative study. International Journal of Sociology and Social Policy, 10 (23): 74-105.

Michel J.B., Shen Y.K., Aiden A.P., Veres A., Gray M.K., Pickett J.P., Aiden E.L. (2011) Quantitative analysis of culture using millions of digitized books. Science, 331 (6014): 176-182.

Olausson U. (2009) Global warming - global responsibility? Media frames of collective action and scientific certainty. Public Understanding of Science, 4 (18):421-436.

Rivkin-Fish M. (2010) Pronatalism, Gender Politics, and the Renewal of Family Support in Russia: Toward a Feminist Anthropology of 'Maternity Capital'. Slavic Review, 3 (69): 701-724.

Robinson P. (2001) Theorizing the Influence of Media on World Politics. Models of Media Influence on Foreign Policy. European Journal of Communication, 4 (16): 523-544. 
Nadezhda Radina

\section{INDEPENDENT MEDIA AND INITIATIVES IN STATE FAMILY POLICY DURING THE 'PRONATALIST TURN'}

The article analyses changes in how family relations are framed in the texts of independent mass media before and after the 'pronatalist turn' in Russian family policy in 2006 . The research question problematises the whether the mass media is able to build strategies not only aimed at submission to political power, but also at resistance, especially in cases where mass media put themselves in a position of independent opposition to political influence. Culturomics, a research method geared towards cultural and social processes with the use of statistical analysis of how words and word combinations are used in a variety of texts, can be employed as a tool for gathering empirical data. Based on statistical analysis of word usage in the media, this paper considers how the frame-structure 'sem'ya' (family) typical of a certain period in the Russian family policy evolution is being constructed. The content of the articles depicting family relations in the media is subjected to statistical analysis of word combination ('trigrams') usage. The archives of a social and political online edition 'Gazeta.ru', the Russian daily social and political newspaper Kommersant; the daily analytical newspaper RBK; and the Russian weekly social and political newspaper 'Novaya gazeta' were all analysed (2000-2015). According to the results of the study, strategies of 'narrative resistance' are not actually used. It is concluded that political elites in Russia do not view family policy as a space for the realization of political interests.

Keywords: family policy, mass media, pronatalism

DOI: 10.17323/727-0634-2018-16-2-295-310

\section{References}

Ananova (2002) Telefonnaja svjaz' - vazhnaja chast' semejnyh otnoshenij [Telephone is an Important Part of Family Relationships]. RBK. Available at: https:/www.rbc.ru/society/ 30/04/2002/5703b6c19a7947783a5a60eb (accessed: 17 May 2018).

Bonch-Osmolovskaya A.A. (2015) Kul'turomika v natsional'nom korpuse russkogo yazyka, k postanovke zadachi: tri veka russkikh dorog [Culturomics in the National Building of the Russian Language, to the Formulation of the Problem: Three Centuries of Russian Roads]. Trudy instituta russkogo yazyka im. V. V. Vinogradova [Proceedings of the Institute of Russian language. V. V. Vinogradova], (6): 605-641.

Nadezhda K. Radina - Dr. of Political Science, professor, Department of Social Sciences; National Research University Higher School of Economics, Nizhny Novgorod, Russian Federation. Email: nradina@hse.ru 
Butler J. (2002) Psikhika vlasti: teorii sub"ektsii [The Psychic Life of Power: Theories in Subjection]. St. Petersburg: Aleteyya.

Carlson J. (1995) Television Entertainment and Political Socialization. P. Vermeer (ed.) 'Media' Res: Readings in Mass Media and American Politics. New York: McGraw-Hill:47-55.

Chernova Zh.V. (2011) Semeynaya politika v sovremennoy Rossii: 'pyatyy natsproekt' [Family Policy in Modern Russia: 'The Fifth National Project']. Chelovek. Soobshchestvo. Upravlenie [Man. Community. Control], (2): 100-113.

Dispensa J. M., Brulle R. J. (1981) The Media's Social Construction of Environmental Issues: Focus on Global Warming. International Journal of Sociology and Social Policy, 10 (23): 74-105.

Gosduma (2014) Gosudarstvennaya semeynaya politika v Rossiyskoy Federatsii [State Family Policy in the Russian Federation]. Moscow: Izdanie gosudarstvennoy Dumy.

Iarskaya-Smirnova E. (2010) 'Da-da, ya vas pomnyu, vy zhe u nas neblagopoluchnaya sem'ya!' Diskursivnoe oformlenie sovremennoy rossiyskoy politiki ['Yes, yes, I Remember You, You are Our Dysfunctional Family!' Discursive Design of Modern Russian Politics]. Zhenshchina v rossiyskom obshchestve [Woman in Russian Society], (2): 14-25.

Livejournal.com (2012) Komu prinadlezhat oppozitsionnye SMI ili demokratiya dlya chaynikov [Who Owns the Opposition Media or Democracy for Dummies]. Available at: http:// mobilization-ru.livejournal.com/754.htm (accessed: 15 December 2016).

Luhmann N. (2001) Vlast' [Power]. Moscow: Praksis.

Luhmann N. (2005) Real'nost' massmedia [The Reality of the Mass Media]. Moscow: Praksis.

Lyashevskaya O. N., Sharov S. A. (2009) Chastotnyy slovar' sovremennogo russkogo yazyka (na materialakh Natsional'nogo korpusa russkogo yazyka) [Frequency Dictionary of the Modern Russian Language (on the Materials of the National Corpus of the Russian Language)]. Moscow: Azbukovnik.

Michel, J. B., Shen, Y. K., Aiden, A. P., Veres, A., Gray, M. K., Pickett, J. P., Aiden E. L. (2011) Quantitative Analysis of Culture Using Millions of Digitized Books. Science, 331 (6014): 176-182.

Olausson U. (2009) Global Warming - Global Responsibility? Media Frames of Collective Action and Scientific Certainty. Public Understanding of Science, 4 (18):421-436.

Otdelkina T.N. (2013) Gosudarstvennaya semeynaya politika kak faktor uspeshnosti razvitiya sem'i [State Family Policy as a Factor in the Success of Family Development]. Vestnik Nizhegorodskogo universiteta im. N.I. Lobachevskogo. Seriya: Sotsial'nye nauki [Bulletin of the Nizhny Novgorod University. NI Lobachevsky. Series: Social Sciences], 2 (30):44-47.

Ozhegov S. I., Shvedova N. Yu. (2006) Tolkovyy slovar' russkogo yazyka [Explanatory Dictionary of the Russian Language]. Moscow: ITI Tekhnologii.

Pecherskaya N. (2012) Mifologiya roditel'stva: analiz diskursivnogo proizvodstva ideal'noy sem'i [The Mythology of Parenthood: An Analysis of the Discursive Production of an Ideal Family]. Zhurnal issledovaniy sotsial'noy politiki [Journal of Social Policy Studies], 10 (3): 323-342. 
Putin V. V. (2006) Poslanie Prezidenta Federal'nomu Sobraniyu Rossiyskoy Federatsii, 2006 [Message of the President to the Federal Assembly of the Russian Federation]. Available at: http://www.doxa.ru/analit/putin2006root.html (accessed: 15 December 2016).

Radina N.K. (2017) Upravlenie massmediynym diskursom kak funktsiya kommunikativnogo koda vlasti [Management of mass media discourse as a function of a communicative power code]. Politicheskaya nauka [Political Science], (2): 138-156.

RBK (2015) Astahov nazval normal'nymi i zakonnymi rannie braki v Chechne [Astakhov Said Early Marriages are Normal and Legal in Chechnya]. Available at: https://www.rbc. $\mathrm{ru} /$ rbcfreenews/5554c7fa9a7947ece0172af9 (accessed: 17 May 2018).

Rivkin-Fish M. (2010) Pronatalism, Gender Politics, and the Renewal of Family Support in Russia: Toward a Feminist Anthropology of 'Maternity Capital'. Slavic Review, 3 (69): 701-724.

Sidorenko E. V. (2002) Terapiya I trening v koncepcii alfreda adlera [Therapy and Training in the Concept of Alfred Adler]. St. Petersburg: Rech.

Robinson P. (2001) Theorizing the Influence of Media on World Politics. Models of Media Influence on Foreign Policy. European Journal of Communication, 4 (16): 523-544.

Zdravomyslova E., Temkina A. (eds.) (2007) Rossiyskiy gendernyy poryadok: sotsiologicheskiy podkhod [Russian Gender Order: Sociological Approach]. St. Petersburg: Izdatel'stvo Evropeyskogo universiteta v Sankt-Peterburge. 